\title{
BOOK REVIEWS / BOEKRESENSIES
}

S. D. (Fanie) Snyman. Malachi. HCOT. Leuven: Peters, 2015. 194 pages, soft cover, price unknown. ISBN 978-90-429-3170-1.

The book of Malachi and Fanie Snyman is almost synonymous, at least within South African scholarly circles. Old Testament prophecy in general and the Minor Prophets in particular always have been of particular interest to him. The bulk of his research has been on Malachi, though. This makes Snyman well suited to write a commentary on this last book of the Christian Canon.

Most OT scholars are already familiar with the format of the series Historical Commentary of the Old Testament, and this commentary on the book of Malachi follows the format that we have become accustomed to: it consists of a new translation, essentials and perspectives, a scholarly exposition including an introduction to and a verse by verse exegesis of the book of Malachi.

Although Snyman has written a lot on Malachi in the past, this latest commentary of his incorporates the most recent research on the book of Malachi and provides the reader with a fresh translation where more than one possible translation is given at some problematic verses. The bibliography is extended, including the latest publications on Malachi, and the reader will find it to be a handy reference tool for further reading and especially for his/her own research on the book of Malachi.

One of the main problems of Malachi is its form. Snyman has thus decided not to focus on one of the proposals made in the history of research. $\mathrm{He}$ is of the opinion that no single description of a particular genre would capture the genre(s) used in the book. Snyman therefore argues that the book made use of a number of genres, blended them together so that the end result is a mixture of genres.

The stylistic device of antithesis used predominantly in the book of Malachi is highlighted and in this way illustrates the impact this has on the understanding of the book. Snyman also reconsiders the demarcation of some of the units in the book. He furthermore reflects on the theological message of each unit as well as of that of the book as a whole.

What one does miss in this commentary is more reflection on the formation of the Book of the Twelve as a collection and Malachi's roll and position in it. The focus in this commentary is on Malachi though, and one may overlook this fact. We cannot really say that groundbreaking work is presented in this commentary, but that does not take anything away from its value. It is a very useful and handy commentary and Snyman's respect for the text and his hesitance to jump to hasty conclusions is commendable. 
Students, pastors and scholars will all benefit from this commentary and it is indeed a highly recommendable piece of work.

S. I. (Fanie) Cronjé, P.O. Box 11248, Queenswood, 0121, Republic of South Africa. Doi: http://dx.doi.org/10.17159/2312-3621/2017/v30n1a11

Tobias Häner, Bleibendes Nachwirken des Exils: Untersuchung zur kanonischen Endgestalt des Ezechielbuches. HBSt 78. Freiburg i.Br.: Herder, 2014. xii + 603 pages, hardcover, $€$ 75.00. ISBN 978-3-451-31578-7.

Bei der vorliegenden Studie handelt es sich um die geringfügig überarbeitete Dissertation von Tobias Häner, die im Wintersemester 2013/2014 unter Franz $\mathrm{X}$. Sedlmeier an der Universität Augsburg angenommen wurde. Die Studie nimmt die Dramaturgie des gesamten Ezechielbuches, wie es uns im masoretischen Text vorliegt, in den Blick, ,um die vom Buchganzen ausgehende ästhetische Wirkung zu eruieren“" (S.1). Methodisch geht Häner dabei so vor, dass er der Leserichtung des Textes folgt, also zurückliegende Texte als dem Leser bekannt voraussetzt (Lesererinnerung), so dass an jedem Punkt der Lektüre eine Vorstellung der noch kommenden Inhalte evoziert wird (Lesererwartung), wobei diese Vorstellungen im Lektüreverlauf stetig korrigiert werden (S.22f.). Wichtig ist dabei, stets die Makrostruktur des Buches im Blick zu haben, um die Bedeutung der einzelnen Abschnitte in der und für die Buchdramaturgie zu erfassen. Dafür folgt Häner strikt den Textsignalen, d.h. Schlüsselwörtern und -formulierungen, durch welche die Texte miteinander vernetzt sind. Darüber hinaus fragt Häner aber auch konsequent nach intertextuellen Bezügen zu anderen Texten des hebräischen Kanons, wobei er „den Bezügen zu den Segensverheissungen und Strafansagen in Lev 26“ eine vorrangige Bedeutung beimisst,

da diese in Ez 5,5-17 programmatisch eingeführt werden, sodann über die Gerichtsankündigungen an Jerusalem und Israel von Ez 424 hinaus sich auch in den Heilsansagen in Ez 33-39 fortsetzen und somit im Buchganzen eine prägende Wirkung entfalten (S.24).

Was die Makrostruktur des Buches betrifft, so ergibt sich Häners Gliederung des Ezechielbuches im Verlauf des Buches (und kann natürlich von Vornherein im Inhaltsverzeichnis eingesehen werden), ohne dass er dazu eine eigene Diskussion in der Einleitung vorlegt. Häner gelangt zu folgender Gliederung:

Ez 1-3 Einleitung Der Eintritt des Lesers in die Buchlektüre

Ez 4-11 1.Akt „Das Ende kommt!“ (Ez 7,2)

Ez 12-24 2.Akt „Kehrt um und lebt!“(Ez 18,32)

Ez 25-32 3.Akt „Ich gebe meinen Schrecken über das Land der Lebenden“" (Ez 32,32) 
Students, pastors and scholars will all benefit from this commentary and it is indeed a highly recommendable piece of work.

S. I. (Fanie) Cronjé, P.O. Box 11248, Queenswood, 0121, Republic of South Africa. Doi: http://dx.doi.org/10.17159/2312-3621/2017/v30n1a11.

Tobias Häner, Bleibendes Nachwirken des Exils: Untersuchung zur kanonischen Endgestalt des Ezechielbuches. HBSt 78. Freiburg i.Br.: Herder, 2014. xii + 603 pages, hardcover, $€$ 75.00. ISBN 978-3-451-31578-7.

Bei der vorliegenden Studie handelt es sich um die geringfügig überarbeitete Dissertation von Tobias Häner, die im Wintersemester 2013/2014 unter Franz $\mathrm{X}$. Sedlmeier an der Universität Augsburg angenommen wurde. Die Studie nimmt die Dramaturgie des gesamten Ezechielbuches, wie es uns im masoretischen Text vorliegt, in den Blick, ,um die vom Buchganzen ausgehende ästhetische Wirkung zu eruieren“" (S.1). Methodisch geht Häner dabei so vor, dass er der Leserichtung des Textes folgt, also zurückliegende Texte als dem Leser bekannt voraussetzt (Lesererinnerung), so dass an jedem Punkt der Lektüre eine Vorstellung der noch kommenden Inhalte evoziert wird (Lesererwartung), wobei diese Vorstellungen im Lektüreverlauf stetig korrigiert werden (S.22f.). Wichtig ist dabei, stets die Makrostruktur des Buches im Blick zu haben, um die Bedeutung der einzelnen Abschnitte in der und für die Buchdramaturgie zu erfassen. Dafür folgt Häner strikt den Textsignalen, d.h. Schlüsselwörtern und -formulierungen, durch welche die Texte miteinander vernetzt sind. Darüber hinaus fragt Häner aber auch konsequent nach intertextuellen Bezügen zu anderen Texten des hebräischen Kanons, wobei er „den Bezügen zu den Segensverheissungen und Strafansagen in Lev 26“ eine vorrangige Bedeutung beimisst,

da diese in Ez 5,5-17 programmatisch eingeführt werden, sodann über die Gerichtsankündigungen an Jerusalem und Israel von Ez 424 hinaus sich auch in den Heilsansagen in Ez 33-39 fortsetzen und somit im Buchganzen eine prägende Wirkung entfalten (S.24).

Was die Makrostruktur des Buches betrifft, so ergibt sich Häners Gliederung des Ezechielbuches im Verlauf des Buches (und kann natürlich von Vornherein im Inhaltsverzeichnis eingesehen werden), ohne dass er dazu eine eigene Diskussion in der Einleitung vorlegt. Häner gelangt zu folgender Gliederung:

Ez 1-3 Einleitung Der Eintritt des Lesers in die Buchlektüre

Ez 4-11 1.Akt „Das Ende kommt!“ (Ez 7,2)

Ez 12-24 2.Akt „Kehrt um und lebt!“(Ez 18,32)

Ez 25-32 3.Akt „Ich gebe meinen Schrecken über das Land der Lebenden“" (Ez 32,32) 

„Wenn sie auf ihrem Boden sicher wohnen und niemand sie schreckt" (Ez 39,26)
Ez 40-48 5.Akt
„Ich will euch gnädig annehmen“ (Ez 43,27)

Ez 33-39 4.Akt

Die Einleitung (Ez 1-3) gliedert Häner in drei Teile: Die Eröffnungspassage 1,1-3 führt den Leser ins Buchganze ein, indem einerseits intertextuell auf andere Prophetenbucheröffnungen angespielt wird (VV 2-3), die dadurch evozierten Erwartungen aber auch durchkreuzt werden (V 1), so dass das Buch als Prophetenbuch doch in seiner Eigenheit von Anfang an in den Blick kommt: Die narrative Buchgestalt, die Verborgenheit des Propheten hinter dem „Ich“ JHWHs, der grosse Anteil an visuellen Elementen und die Unmittelbarkeit, die ihn ohne äusseren Blickpunkt in das Erleben des Propheten hineinnimmt. Auf diese Eröffnungspassage folgt die Vision der kabod JHWH (1,4-28), die den Propheten für seinen Auftrag beglaubigt, die aber auch auf Gericht und Heil vorausweist. Die weiteren Visionen der kabod JHWH folgen im ersten (Ez 8-11) und letzten (Ez 43) Akt und rahmen damit das ganze Buch. Schliesslich folgt in Ez 2,1-3,27 als Exposition das Indienstnahmegeschehen, wobei durch die Indienstnahme des Propheten und durch die Charakterisierung der Adressaten die in den ersten zwei Akten erfolgende Gerichtsankündigung eingeleitet wird.
\end{abstract}

Auch für den ersten Akt (Ez 4-11) macht Häner drei Teile aus: Die Zeichenhandlungen $(4,1-5,4)$ leiten thematisch in die Belagerung und Einnahme Jerusalems ein, die anschliessenden Gerichtsworte $(5,5-7,27)$ deuten das Strafgericht mit Bezug auf Lev 26 im Rahmen des gebrochenen Sinaibundes. Diese Vergehen werden dann in der Tempelvision Ez 8-11 zunächst vor Augen geführt (Ez 8). Durch die drei Ausrufe in 4,14; 9,8 und 11,13 wird die Spannung in Gottes Gerichtshandeln angesprochen, einerseits, dass auch Unschuldige vom Gericht getroffen werden, andererseits, dass das Gericht in der Vernichtung des Gottesvolkes zu enden scheint. Diese Spannung wird durch die Heilsverheissung in 11,17-20 aufgelöst, doch der Akt endet nicht mit diesem Heilsausblick, sondern damit, dass die Thronherrlichkeit JHWHs Tempel und Stadt verlässt.

Der zweite Akt (Ez 12-24) setzt die Gerichtsankündigung des ersten Aktes fort, verschiebt aber den Akzent, ,da nun die Gola als Adressatin dieser Gerichtsbotschaft vermehrt in den Blick kommt" (S.194). Die ersten beiden Akte sind durch diverse Bezugnahmen auf Lev 26 miteinander verbunden, wobei sich Ez 5-7 auf Lev 26,14-33 bezieht, Ez 14-24 dagegen diverse Bezugnahmen auf Lev 26,34-45 enthält. Häner spricht für den zweiten Akt von zwei Phasen, wobei die erste Phase (12-19) die Notwendigkeit der Umkehr der Exilierten betont, die zwar das Gericht über Jerusalem nicht abwenden kann, auf der aber die Verheissung des Lebens (Ez 18) steht. Doch wird deutlich, dass der Widerstand gegen die Botschaft Ezechiels bestehen bleibt. Die zweite Phase beginnt mit Ez 20, nach Häner einem Schlüsseltext für den zweiten Akt 
und das ganze Buch, welcher die Notwendigkeit des kommenden Gerichtes, gerade auch für ein neues Heilshandeln, verdeutlicht. Ez 21-24 intensiviert sodann die Gerichtsankündigungen, ohne dass ein neuerlicher Heilsausblick erfolgt. Ez 24, gerahmt durch zwei Schicksalstage (den Tag, an dem die Belagerung Jerusalems beginnt und den Tag, an dem die Nachricht des Falls Jerusalems in der Gola eintrifft), schliesst den zweiten Akt ab.

Im Übergang von Ez 24 zu Ez 25 und damit zum dritten Akt (Ez 25-32), den Fremdvölkersprüchen, wird deutlich, dass sich das über Jerusalem beschlossene Gericht auch auf die Völker ausbreitet. Häner arbeitet Ez 28,2026 als strukturelle und inhaltliche Mitte des dritten Aktes heraus, die in Ez 28,25-26a in eine Heilsansage für Israel mündet. Auch sonst achtet Häner auf indirekte Heilsankündigungen, die deutlich machen, dass in der Gerichtsansage an die Völker auch Hoffnung für Israel enthalten ist. Indem das Prachtschiff von Tyrus wegen seiner kabod im Meer versinkt $(27,25)$ und auch der Pharao mit seiner kabod in die Unterwelt gezogen wird $(31,18)$, wird der Leser eingeladen, JHWH als alleinigen Regisseur der Weltgeschichte zu erkennen (Rückbezug auf die Vision der kabod Jahwes in Ez 1; siehe S.356f.)

Der vierte Akt (Ez 33-39) leitet die dramaturgische Wende vom Gericht zum Heil ein. Der Akt beginnt mit Kapitel 33, einem Kapitel, in dem sich die Rückbezüge zum vorangehenden Ezechielbuch (bes. Ez 2-3; 12-13; 18; 24) verdichten. Wie im zweiten Akt sind die Exilierten wieder direkt angesprochen und zur Umkehr aufgerufen. Am Ende des Kapitels trifft die Nachricht von Jerusalems Untergang in der Gola ein, doch eine Umkehr bleibt aus. An diese Voraussetzung schliesst Ez 34-39 an: „In Hinblick auf die nachfolgende Heilsankündigung wird dadurch die Fähigkeit der Exilierten, durch Umkehr an der verheissenen Wiederherstellung zu partizipieren, stark relativiert" (S.384). Die über diverse Stichworte miteinander verbundenen Kapitel 34-37 kumulieren sich zur Erkenntnis, dass die Wiederherstellung Israels nicht der Endpunkt des Heils ist, sondern nur das Mittel, durch das sich der Segen aus Lev 26 entfalten kann. Eine zentrale Bedeutung in diesen Heilsverkündigungen hat die Scham, die nicht durch Gericht, sondern durch die (unverdiente) Segensfülle hervorgerufen wird:

Die wirkungsästhetische Funktion der Bezüge zu Lev 26 besteht folglich darin, die bleibende Unfähigkeit Israels, der göttlichen Erwählung zu entsprechen und dem Bundesverhältnis mit Gott Bestand zu geben, ins Bewusstsein zu heben und so die Erwählung zum Volk Gottes nicht als Auszeichnung vor den Völkern zu betrachten, was zum Hochmut verleiten könnte, sondern sie als demütigenden, aufgrund des Bewusstseins der eigenen Schuldverfallenheit beschämenden göttlichen Akt wahrzunehmen (S.458).

Die Gog-Perikope (Ez 38-39) vervollständigt die Segensfülle aus Lev 26 und mündet in die Scham Israels für Israels Gotteserkenntnis (39,26-29). 
Auch wenn der fünfte Akt (Ez 40-48) sprachlich und konzeptuell eine stärkere Eigenständigkeit hat, gelingt es Häner, zu zeigen, dass er den Höhepunkt des ganzen Ezechielbuches bildet. Ez 40,1-4 weist mit der Datierung und diversen Stichworten auf den Buchanfang Ez 1,1-3 zurück, in der Mitte von Ez 40-48 steht die Vision der Rückkehr der kabod JHWHs, so dass Ez 40-48 insgesamt die Tempelvision in Ez 8-11 aufgreift und das positive Gegenstück dazu bildet. Nach Häner ist die das ganze Buch beherrschende Theozentrik im fünften Akt kultisch inszeniert:

Zielte also der dramaturgische Aufbau des Buches bis zum Ende des vierten Aktes darauf hin, dem Leser Exilierung und Rückführung Israels als JHWHs Handeln in der Geschichte zu vergegenwärtigen [...], so wird er nun auf das Ziel dieses Erkenntnisvorgangs verwiesen, nämlich auf die Rückgewinnung der eigenen Identität, die nur von JHWH bewirkt werden kann durch die Vergebungszusage. Letztere unterfängt die sich in der Scham ausdrückende Reue und ermöglicht es so, Gott gegenüberzutreten, ihm (im Kult) zu begegnen (S.542).

Gerade die Einfügung von Ez 40-48 in das Buchganze als fünfter Akt und Höhepunkt des Buches, ist ein grosses Verdienst von Häner, zumal dieser Buchteil allzu oft völlig separiert vom restlichen Ezechielbuch ausgelegt wurde.

Insgesamt wird die Studie Häners dem höchsten Anspruch exegetischen Arbeitens, nämlich dem vertieften Verständnis des Textes, vollumfänglich gerecht. Mit dieser ausgesprochen gründlichen und sorgfältigen Untersuchung legt er zugleich einen überzeugenden Beweis der grossen Leistungsfähigkeit einer synchronen Analyse zum Textverständnis vor, der viele diachrone Studien, die den Anspruch haben, dass nur von der Frage nach der Textentstehung her der Text in seiner geschichtlichen Tiefe wirklich verstanden werden kann, bei weitem überbietet. Auch wenn sich Häners Erkenntnis mit den Erkenntnissen holistischer Ansätze (Greenberg, Block, u.a.) oft überschneiden, bedeutet sein Ansatz freilich nicht, dass Häner selbst einen solchen Ansatz vertritt. So vermutet er etwa, dass die Gog-Perikope ein jüngeres Textsegment darstellt (S.459) und macht auch sonst gelegentlich kleine Hinweise auf eine mehrstufige Textentstehung, ohne diese Annahmen freilich zu Bedingungen des Textverständnisses zu machen.

Im Rahmen dieser Rezension konnte leider im Durchgang durch die einzelnen Teile nicht genügend gewürdigt werden, wie stark Häner mit Textsignalen, insbesondere mit Stichwortverknüpfungen, durch das ganze Ezechielbuch hindurch arbeitet. Es gelingt ihm immer wieder, zu zeigen, dass Kapitelabfolgen, die oft als disparat wahrgenommen werden, durch Stichwortverbindungen deutlich aufeinander bezogen sind. Auch intertextuell macht er viele wertvolle Beobachtungen, wobei der Erkenntnis, dass das 
Heiligkeitsgesetz (besonders Lev 26) eine wichtige Vorlage für das Ezechielbuch bildet, eine besonders grosse Bedeutung zukommt (so auch schon R. Levitt Kohn und M. Lyons).

Etwas mehr Klärung hätte ich mir bezüglich des angenommenen „Lesers“ gewünscht. Einerseits weist Häner verschiedentlich auf Passagen hin, in welchen die Gola direkt adressiert wird, andererseits scheint er eine Leserschaft vorauszusetzen, die schon auf die Wiederherstellung zurückblickt (siehe z.B. S.562). Als Leserschaft des masoretischen Textes, der die Grundlage seiner Untersuchung bildet, wäre sodann an die jüdische Synagoge in der Spätantike/dem Mittelalter zu denken, während mit dem Leser auch der heutige Leser gemeint sein kann. Wie ist diesen unterschiedlichen Lesehorizonten Rechnung zu tragen? Macht es für die Lektüre einen Unterschied, ob der „Erstleser" in der Gola zu verorten ist (was den im Ezechielbuch gesetzten Daten entspricht), oder ob eine nachexilische Leserschaft angesprochen ist, für welche die Ereignisse bereits als mit dem Prophetenwort übereinstimmend erwiesen haben (siehe S.557)?

Aufgrund des grossen Buchumfangs ist es äusserst hilfreich, dass Häner sehr darum bemüht ist, immer wieder zu resümieren und Überblicke über Zwischenresultate zu geben. Dennoch fällt es bei fortlaufender Lektüre schwer, den Wald vor lauter Bäume zu sehen. Erschwert wird die Lektüre auch durch teilweise recht umständliche, verschachtelte Sprache mit Sätzen, die man manchmal mehrere Male lesen muss. Aber vielleicht darf ein Buch zu Ezechiel nicht anders geschrieben sein, als so, dass man zu langsamem Lesen gezwungen wird. Alles in allem ist das Buch ein grosser Wurf und hat mein eigenes Verständnis dieses „schwierigen“ Propheten sehr bereichert.

Benjamin Kilchör, Staatsunabhängige Theologische Hochschule Basel (Switzerland) and Dept. of Ancient Languages at the University of Pretoria (South Africa), Grüenaustrasse 21, CH-8624 Grüt (Switzerland). Email: benjamin.kilchoer@sthbasel.ch. Doi: http://dx.doi.org/10.17159/2312-3621 /2017/v30n1a12. 
Origenes: Die Homilien und Fragmente zum Hohelied: Eingeleitet und übersetzt von Alfons Fürst und Holger Strutwolf. Origenes: Werke mit deutscher Übersetzung 9/2. Berlin, Boston: de Gruyter, 2016. vi + 288 pp., cloth, $€$ 70. ISBN 978-3-11-046161-9.

This is the one of two new volumes in the series Origenes: Werke mit deutscher Übersetzung - Im Auftrag der Berlin-Brandenburgischen Akademie der Wissenschaften und der Forschungsstelle Origenes der Westfälischen Wilhelms-Universität, herausgegeben von Alfons Fürst und Christoph Markschies. Started in the year 2009, this series will eventually contain 25 volumes, see https://www.degruyter.com/view/serial/38285 and http://www .antikes-christentum.de/de/forschung/origenes/apokryphen31. The present volume is the companion volume to Origenes, Der Kommentar zum Hohelied, also edited and translated by Alfons Fürst and Holger Strutwolf (Origenes: Werke mit deutscher Übersetzung 9/1; Freiburg: Herder; Berlin, Boston: de Gruyter, 2016; 488 pp, ISBN 978-3-451-32913-5).

The present volume presents the Latin and Greek texts (without critical apparatus) according to the editions of Adolf Baehrens for the two homilies (Origenes Werke Achter Band: Homilien zu Samuel I, zum Hohelied und zu den Propheten: Kommentar zum Hohelied in Rufins und Hieronymus' Übersetzungen, GCS 33 = Orig. 8; Leipzig 1925, 26-60) and for the fragments, the critical edition of the Catena of Procopius on the Song of Songs edited by JeanMarie Auwers (Procopii Gazaei Epitome in Canticum Canticorum, edita a J.M. Auwers cum praefatione a J.- M. Auwers, M.- G. Guérard, curata, CChr.SG 67, Turnhout, 2011).

What makes the volume particularly valuable are the more than 360 notes to the running text which also include cross references to other works of Origen and the detailed introductions. The introduction of the two homilies on the Song of Songs (3-37) discusses the nature of the Latin translation of Jerome (in 383/4 in Rome), the literary character of these homilies (with a brief discussion of Origen's hermeneutics) and surveys the theology and spirituality of Origen's interpretation. It is characterised by a deep longing for God (the dramatic scenery and its spiritual significance), universal Eros (Platonic and biblical concepts of love), the relationship between Eros and Psyche (the individuality of love) and love with all senses (Origen's theory of spiritual senses). The editors also describe the homilies' tradition and edition history.

The introduction to the Greek fragments of Origen on passages from the Song as preserved in the Catena of Prokopius of Gaza on the Song of Songs (37-56), first describes the fragment from the minor commentary on the Songs from Origen's early works and then the fragments from the major commentary on the Songs. Discussion includes the literary character and value of the fragments from various catenae, foundational presuppositions behind the interpretation and the goal of love as the ascent of the soul and flight with the 
One. The editors further sketch the history of tradition and edition and provide a helpful synopsis of the numbering of the fragments in different editions (5456). The introduction closes with an index of the verses of the Song which Origen commented upon in the homilies and the 95 fragments (56-59). The volume closes with a bibliography (editions and translations of the homilies and the fragments, 249-252, secondary literature, 252-257) and indexes of biblical references, references to other works of Origen, and of names and subjects.

The volume is important for students of the Christian reception history of the Song and of the history of biblical interpretation. It also offers insights for the study of Christian spirituality and the understanding of sexuality and bodies.

Other volumes in the series on OT books are: Band 1/1: Die Kommentierung des Buches Genesis; Band 1/2: Die Homilien zum Buch Genesis; Band 7: Die Homilien zum Ersten Buch Samuel; Band 10: Die Homilien zum Buch Jesaja; Band 11: Die Homilien zum Buch Jeremia.

Jerome's preface and dedication of his translation of Origen's two homilies to pope Damasus is worth quoting in closing:

Während Origenes bei den übrigen Büchern (sc. der Bibel) alle übertroffen hat, hat er sich beim Hohelied selbst übertroffen. Denn in zehn Bänden [the commentary], die sich auf fast zwanzigtausend Zeilen belaufen, erörterte er zuerst die Übersetzung der Siebzig, dann Aquila, Symmachus, Theodotion und schließlich die fünfte Ausgabe, die er, wie er schreibt, an der Küste von Aktium gefunden hat, auf so glanzvolle und klare Weise, dass sich mir an ihm das Schriftwort erfüllt zu haben scheint: „Der König hat mich in sein Gemach geführt." Daher habe ich dieses Werk beiseite gelassen, da es ungeheuer viel Zeit, Mühe und Kosten erfordert, so bedeutende Dinge in angemessenes Latein $\mathrm{zu}$ übertragen. Die beiden vorliegenden Abhandlungen hingegen, die er im Stil der Alltagssprache für Kinder, die noch gesäugt werden, verfasst hat, habe ich eher zuverlässig als kunstvoll übersetzt. Ich riete dir damit eine Kostprobe seiner Gedanken an, nicht die Speise selbst, damit du erkennst, wie hoch jenes große Werk zu schätzen ist, wenn schon das kleine so zu gefallen vermag (63).

Prof. Dr. Christoph Stenschke, Dozent der Biblisch-Theologischen Akademie, Forum Wiedenest, Eichendorffstr. 2, 51702 Bergneustadt, Germany. Professor extraordinarius am Department of Ancient and Biblical Studies, University of South Africa (Pretoria). privat: Bahnhofstrasse 1, 51702 Bergneustadt, Germany, Tel. 0049 (0) 2261 - 9145 85, Email: Stenschke@wiedenest.de. Doi: http://dx.doi.org/10.17159/2312-3621/2017 /v30n1a13. 
Hans Ausloos. The Deuteronomist's History: The Role of the Deuteronomist in Historical-Critical Research into Genesis-Numbers. Leiden/Boston: Brill, 2015. xvii + 429 pages, soft cover, price unknown. ISBN: 978-90-0429676-3.

This book deals with a problem which has occupied scholars of the Jewish Bible for more than two hundred years, leaving it still unresolved and therefore represents an in-depth study of a highly relevant theme.

The Roman-numbered pages cover a preface, a list of abbreviations and a table of contents. The body of the book (337 pages) consists of five chapters dealing respectively with studies from the 18th and 19th centuries of Deuteronom(ist)ic elements in the Tetrateuch, studies ever since focusing on Exod 23:20-33, the epilogue of the Book of the Covenant, studies amongst the latter from the middle of the 20th century which proposed a protoDeuteronom(ist)ic background, studies since the 1970's of the origin and composition of the Pentateuch and, finally, a critical overview of this whole "history" of the Deuteronomist linking it to the wide and confusing terminology (such as pre-, proto-, Deuteronomic, late-, post-, Deuteronomisitic and anti-Deuteronom[isti]ic), lack of objective criteria and textual criticism. The latter actually shows these different phases of a continuing process of harmonisation with the normative Deuteronomistic influence.

The book concludes with a bibliography (57 pages, 1100 sources in 5 different languages and from various continents), an index of authors mentioned and an index of Biblical references.

Perhaps due to its translation from the original Dutch and due to the density of its detail and footnotes, the book is not always easy to read. The title might also be misleading as the intention is both to describe the different views held over the last three centuries about the relationship between the first four books of the HB and the Deuteronomist, and the history of this relationship itself. Apart from a few orthographical errors, there is also a mistake on page $\mathrm{x}$ in that the reign of King Josiah was not during the 8th but the 7th century BCE instead.

The various and divergent views about this relationship are critically examined and exposed as problematic, emphasising that the issue is far from resolved. The final chapter expresses the need for the identification of different phases in the development of Deuteronom(ist)ic literature. As one such phase or rather phenomenon, the term, simili-Deutonomistic, is then added to denote the imitation or similarity of this literature in the ongoing development of other OT books.

In order to identify these phases, two procedures need to be followed: first thorough form (reflected by vocabulary, syntax and compositional schemas, all as used in the specific context and so beyond statistical dominance) 
and especially content analyses are to be made. This concerns both Tetrateuch passages with a Deuteronomistic appearance as well as parallel occurrences in the "Deuteronomistic Canon" as "reference framework" (that is, the book of Deuteronomy, the books of Joshua-2 Kings and certain parts of the book of Jeremiah). Only then can they be compared in terms of similarities and differences. That this scope may be questioned is, however, not thoroughly discussed.

The second procedure follows only when sufficient resemblances in both analyses have been confirmed. Now the nature of the relationship is to be investigated including both the direction of the dependence (cf. the book of Jeremiah) and the dating of this influence. The rest of the OT should then be used as a "controlling framework." The dating of a particular form of Hebrew and the original Sitz im Leben can help to allocate a pericope to a layer in this history. This procedure has, of course, additional value in that it can be generalised to other questions about textual relationships outside of the Deuteronomic one.

The nature of the relationship may be the most difficult in this process of comparison, as a common denominator does not automatically render it Deuteronom(isit)ic. The reason for this is that this would make it a norm which might not be justified and will result in pan-Deuteronomism. This means an allinclusivity which renders the textual relationship meaningless, as every text would be derivative of the Deuteronomist hand, a problem which is not sufficiently dealt with in the book. A comprehensive list with justification of all the typical vocabulary, stylistic features and compositional structures of the Deuteronom(ist)ic hand would have aided in its clear definition and could assist in drawing up criteria for the identification of other Deuteronom(ist)ic texts outside this corpus. The examples of typical themes on p. 296 are a start in that direction with regards to content.

The book therefore deals, firstly, with a particular Pentateuchal problem by limiting the Deuteronom(ist)ic relationship to the first four books of the Jewish Bible and, secondly, with the nature of the Deuteronom(ist)ic hand as such. As the texts of the Tetrateuch are under discussion as to whether they are Deuteronom(ist)ic and could therefore be argued to be somehow part of the Deuteronomistic Canon there seems to be a kind of a petition principii as there are, in fact, two variables.

This book is itself clearly the product of a long and intense engagement with the problem and should be used in the same way as a constant frame of reference rather than as a single encounter to be digested in one session. It should be regarded as competing to be the most up-to-date, critical analysis of a central problem in OT scholarship.

Pieter van der Zwan, University of Pretoria (South Africa). E-mail: pvdz1811@gmail.com. Doi: http://dx.doi.org/10.17159/2312-3621/2017/v30n1a14. 
Willgren, David, The Formation of the 'Book' of Psalms: Reconsidering the Transmission and Canonization of Psalmody in Light of Material Culture and the Poetics of Anthologies. FAT II/88. Tübingen: Mohr Siebeck, 2016. 491 pages, paperback, $€$ 99. ISBN 978-3-16-154787-4.

Bei der vorzustellende Studie handelt es sich um eine in Lund (Fredrik Lindström) eingereichte Dissertation (ThD). Für eine theologische Qualifikationsarbeit ist sie als aussergewöhnlich einzustufen. Sie bearbeitet keine beschränkte Thematik, sondern nimmt die Formierung des Psalmenbuches insgesamt in den Blick. Die Beurteilung geschieht unter Einbezug vergleichbarer Sammlungen in Israel und im Alten Orient. Das Ergebnis ist eine Infragestellung von Prämissen und Ergebnissen der vorherrschenden Psalterforschung (G. Wilson, Hossfeld \& Zenger u.a.). Angesichts dessen ist eine ausführliche Rezension angebracht.

Willgrens gut strukturierte Arbeit enthält sechs Hauptteile, einen „final outlook“" und drei Appendices (Kataloge altorientalischer Incipits; Überschriften MT, Pss-Mss der DSS und LXX; Zusammenstellung von LXX-Mss). Eine umfangreiche Bibliographie und zwei Indices (Stellen, Autoren) erschliessen den Band in hilfreicher Weise.

$\mathrm{Zu}$ Beginn wird die bahnbrechende Arbeit von Gerald Wilson vorgestellt, der erstmals unter Einbezug des Handschriftenmaterials vom Toten Meer den Psalter als editorisches Gesamtwerk beschrieb. Sie führte zur sequentiellen Lesung der Psalmen in kanonischem Horizont. Deren Sitz war in der Literatur (nicht mehr im Kult). Die Annahme einer intentionalen Anordnung der Psalmen und damit verbundener Sinnzuschüsse stellt Willgren in Frage. Seine Kritik richtet sich nicht (nur) auf die Ergebnisse der dominierenden Psalterexegese, sondern zielt auf deren Prämissen und Methodik. Gemäss Willgren sind die Psalmen kein „Buch“ (Komposition), sondern eine Anthologie (Kompilation): „An anthology is a compilation of independent textes, actively selected and organized in relation to some present needs, inviting readers to a platform of continuous dialogue.“ (S. 25). Der Psalter ist kein „Text", sondern ein „Werk“, „Like a Garden of Flowers“ (ursprünglicher Titel der Dissertation). Anthologisten können zwar „Fingerabdrücke“ wie Titelsetzungen, Gruppierung, sogar Hinzufügungen oder Neuinterpretation von Stücken hinterlassen, aber der Eingriff in die Sammlung geschieht beschränkt. Die Einzelstücke behalten ihre Selbstständigkeit und werden nicht in eine Gesamtkomposition überführt.

Die Signatur von Anthologien sind „Paratexte“ (nach G. Genette): beigegebene Marker, welche den Zusammenhalt fördern und das Verstehen leiten. Zum Vergleich werden Sammlungen aus dem alten Orient und der Antike unter die Lupe genommen (sumerische Dekade, Hodajot, Dodekapropheton, sumerische Tempelhymnen, homerische Hymnen). Der Befund zeigt sequentielle Varianten, was Einzelstücke wie Gruppen betrifft. Im Laufe der formativen 
Prozesse existierten alternative Konfigurationen von poetischen Texten; ein „update“ war stets möglich. Gegenüber dem linearen Modell der Psalterforschung weist das untersuchte Vergleichsmaterial auf eine andere Konzeption: „The canonization related primarily to the selection of compositions, and not to their arrangement" (S. 79).

Nach diesen Parallelen werden die am Toten Meer gefundenen PsalmenHandschriften untersucht. Differenzen zum MT im Blick auf die Abfolge der Psalmen liegen in in den Bereichen Ps 103-106 (109), 118-119 und 133-150 vor (Pss mit David-Präskripten oder Halleluja-Rahmen). Von (mindestens) sieben Psalmen-Konfigurationen sind zwei mehr als einmal bezeugt: eine Gruppe in weitgehender Übereinstimmung mit dem MT und eine andere mit 11Q5 $\left(11 \mathrm{QPs}^{\mathrm{a}}\right)$ als Hauptrepräsentanten. Der von (G. Wilson und) P. Flint vertretenen Zwei-Stufen-Stabilisierung (Ps 1-89| 90-150) ist der Abschied zu geben.

Damit kommt Vf. zu den biblischen Psalmen selber (MT) und sichtet sie nach paratextlichen Features. Von besonderer Bedeutung ist, ob Ps 1(-2) eine das Buch einleitende Funktion hat. Entgegen der fast einhelligen Forschungsmeinung verneint Willgren dies: Die „Tora JHWHs“ (Ps 1,2) ist nicht selbstreferentiell-autorisierend (auch) auf den Psalter zu beziehen, sondern meint die „Tora Moses“ (wie Jos 1,8, vgl. 4Q174 II,2-3). Ps 1 und 2 sind als „normale“ Einzelpsalmen zu lesen (Ps 2,12bd ist ein Ps 1 und 2 verbindender Zusatz). Keine harmonisierende Zusammenlesung ist intendiert, vielmehr benachbart der Anthologist die kontrastierenden Psalmen und lädt so ein zu einer „ongoing discussion around three main topics: righteousness, kingship, and refuge" (S. 157). Eine Vorwort-Funktion von Ps 1(-2) ist erst Teil der griechisch-christlichen Rezeption.

Ein Vergleich der Psalmen-Präskripte als Paratexte (MT, DSS, LXX) ergibt im Blick auf die Autor-Bezeichnungen, dass die LXX (mit zusätzlichen David-Zuweisungen) insgesamt und die DSS mehrheitlich dem MT folgen. Die davidisch-biographischen Notizen sind Ausdruck einer fortschreitenden Davidisierung und Autorisierung der Psalmen. Die „Hallelujahs“ finden sich bei 15 Psalmen (ab Ps 104), davon 8mal als Rahmen (DSS-Psalmen und LXX mit abweichendem Befund). Aufs Ganze gesehen haften die Präskripte an den jeweiligen Psalmen und sind nicht als Verbinder von (früheren) Psalmengruppen zu beurteilen. Die Auswertung führt Vf. zu folgendem Drei-Stadien-Modell der Entwicklung: Ps 1-90 | 90-119 | 120-150. Das Kolophon Ps 72,20 (,zu Ende gekommen sind die Gebete Davids, Sohn von Jesse") bezeichnet nicht den Abschluss einer David-Sammlung, sondern markiert „technisch“ das Ende der ersten von zwei Psalmen-Schriftrollen. Was die den Psalter in Teilbücher trennenden Doxologien angeht (Ps 41,14; 72,18-19; 89,53; 106,48), erweisen sich die brk-Doxologien nach Ps 72 und 106 als die ältesten (sie haben die andern beiden ausgelöst). Ein Wachstum entlang der Teilbücher ist nicht haltbar. Das Ende der Fünffach-Struktur bietet (zunächst) nicht Ps 150, sondern Ps 
135-136 (beide Ps mit Fünffach-Struktur, Ps 135 zudem je 5 Impt und brk-Formen). Diese $b r k$-doxologische Sammlung hat ein pentateuchisches, von Leviten verantwortetes Gepräge. Mit der Verknüpfung von brk- und halleluja-Lobpreis markiert Ps 145 (V. 1-2.21) das Bindeglied zum finalen Hallel Ps 146-150, mit dem die brk-Doxologie durch halleluja-Lobpreis abgelöst wird. Eine „concluding function“"von Ps 146-150 (im MT), verbunden durch die Thematik der Königsherrschaft JHWHs, ist anzunehmen.

Hinter der anschliessenden Suche nach Zitaten und Anspielungen (sowie levitischen ,stock-phrases“) auf Psalmen in andern Schriften steht die Frage, ob Merkmale eines Bewusstseins für einen Sitz in der Literatur (Nebeneinanderstellung und Sequenzialität) zu finden sind. Eine Durchsicht der Bibelbücher ergibt einen negativen Befund: Die verschiedenen Sammlungen dienten als Gefässe (,containers“) der Psalmodie; ihr primärer Kontext lag ausserhalb ihrer selbst (Vf. meidet das Wort ,kultisch“). Mit den Prozessen der Sammlung verbanden sich Autorisierung und Schriftwerdung sowie eine zunehmende Assoziierung mit David und den Leviten. Danach werden auch die Handschriften vom Toten Meer entsprechend gesichtet (u.a. 4Q171; 174.177; 380-381; 393; 11Q11 etc.). Die reiche Verwendung von MT-Psalmen zeigt deren Einfluss und bezeugt prophetischen (und davidisierenden) Charakter und Autoritätszuwachs (Schriftwerdung). Dieser kommt einzelnen Psalmen und nicht Psalmensammlungen zu. Bezugnahmen auf Psalmen in antik-jüdischen, neutestamentlichen und frühchristlichen Schriften manifestieren eine (weitere) Verstärkung der Davidisierung sowie deren prophetischen Charakter und damit das Verständnis als Schrift (u.a. Lk 24,44). Die Sequenzen von belegten Psalmen in Sammlungen sind nun weithin fixiert (MT), und ein Kanon(bewusstsein) tritt zutage. Gewisse sequentielle Verwendungen von Psalmen in der Liturgie werden greifbar. Im 1. oder spätestens 2. Jh. n.Chr. ist eine Psalmensammlung in den Konturen von MT und LXX als „Schrift“" anerkannt.

Im Schlusskapitel werden Einsichten gebündelt und formierende Prozesse der Psalmen-Sammlung(en) skizziert: Ein sequentiell stabiler Kern von Psalmen ist ebenso wenig auszumachen wie ein lineares, evolutives Wachstum $\mathrm{zu}$ einem Psalter. Im Laufe der Überlieferung werden Psalmen hinzugefügt, und es kommt zu einer gewissen Stabilisierung von Psalmengruppen (Clustering). Die erste greifbare Sammlung hat die Umrisse von Ps 1-119, steht in deuteronomischer Tradition und ist perserzeitlich anzusetzen. Verantwortet von Leviten verbindet sie Psalmodie und Tora (Rahmen) und bringt Mose und David in einen Dialog. Das nächste formative Stadium gehört in die Zeit der Chronik und endet mit Ps 135-136 als finaler Doxologie. Die Fünfteiligkeit ist nun markiert, die konzeptionelle Verbindung zur Tora Moses verstärkt, und die Überlieferung findet auf zwei Rollen mit vergleichbarem Umfang statt. Das letzte Stadium umfasst in etwa die Gestalt des MT (Ps 1-150). Sie zeichnet sich durch Überlagerung eines Hallelujah-Rahmenwerks aus. Levitischer Einfluss, David und Tora treten zurück, so dass für das Schlussstadium weder eine leviti- 
sche noch eine chronistische Prägung anzunehmen ist (Datierung um 200 v.Chr.).

Die Untersuchung zeigt, dass strikt zwischen der Auswahl (,selection“) von Psalmen und deren Organisierung (,,binding“) innerhalb der Sammlung zu unterscheiden ist. Die Anthologisten waren kontinuierlich vor die Frage des Ein- bzw. Ausschlusses von Psalmen gestellt. Autorität kam nicht der Sammlung zu, vielmehr diente diese umgekehrt als „Behälter“ für autoritative Psalmen. Statt von einem „Buch“ ist von einem „Kanon“ von Psalmen (vergleichbar mit der Formierung der hebräischen Bibel) zu sprechen. Deren Anordnung ist eng verknüpft mit den Modi des Lesens, der Aufführung und Verwendung. Die Nebeneinanderstellung von Psalmen muss nicht zufällig, und Gedankenentwicklungen mögen in Teilen greifbar sein; eine „lineare Lesung“ durch die Psalmen insgesamt ist jedoch nicht zu plausibilisieren (auch Autor-Zuschreibungen markieren keine Abgrenzungen im Blick auf sequentielles Lesen). Vf. illustriert den Sachverhalt anhand eines Kochbuchs: Die Rezepte sind unter Titel und Untertitel gestellt. Die Nebeneinanderstellung ergibt sich aus thematischen Gründen (z.B. Hauptmenüs, Desserts etc.). Die Anthologie lebt aus der Spannung zweier Kräfte: der integrativen (Einfügung in eine Ganzes) und der isolativen (Selbständigerhaltung der einzelnen Stücke). Die jüngere Psalterforschung löst diese Spannung durch die Priorisierung des Integrativen einseitig auf: „The notion of the ,Book“ of Psalms being greater than the sum of its parts in fact results in the ,book ${ }^{6}$ being less than the sum of its parts“ (S. 390). Die Gestalten der ,canons of psalms“ (ab dem 6. Jh. v.Chr.) ist insofern abgeschlossen, als sie auf Rollen geschrieben sind, aber insofern offen, als sie „snapshots“ eines langen Prozesses der Selektion und des Aufbewahrens von Psalmen sind.

Die Psalterforschung wird sich mit dieser Studie intensiv auseinandersetzen müssen. Fürs erste müssen wenige Hinweise der Würdigung und Kritik genügen: Das breite Spektrum der Fragestellungen sowie die materiale Breite der in den Blick genommenen Texte ist eindrücklich. Begrüssenswert ist die weitgehende methodische Trennung zwischen Beobachtungen und Beurteilungen. Dazu tragen die ausführlichen Zusammenstellungen und Tabellen im Buch und in den Appendices - sie sind allein schon wertvoll - bei, die den Stoff aufbereiten und einen Nachvollzug der Einschätzungen ermöglichen. Zu beherzigen ist das Plädoyer des Vf.s für einen verstärkten Einbezug der QumranHandschriften. Die neuste, von Willgren aufgenommene Diskussion zu den Pss-Handschriften (u.a. E. Jain) zeigt, dass der fragmentarische Befund nicht so viel hergibt, wie man meinte (und z.T. überinterpretierte). So ist für 11Q5 kein gesicherter Anfang bzw. Umfang zu erheben. Die Annahme einer Hauptzäsur Ps 89| 90 ist damit nicht hinfällig, aber ihre Stützung durch 11Q5 fragwürdig geworden. Willgrens Hauptkritik an der Betrachtung der Psalmen in literarischer (linearer) Perspektive verdient bedacht zu werden. Das Pendel in der Psalterforschung ist (zu?) stark in Richtung literarische Komposition ausge- 
schlagen. Die Wahrnehmung des Psalters als (individuell verwendetes) Meditationsbuch rückte dadurch in den Vordergrund. Selbst wenn man einer sequentiellen Wahrnehmung der Psalmen (anders als Willgren) positiv gegenüber steht (wie der Rezensent), werden die Einzelpsalmen (auch aufgrund der Präskripte) ja weithin belassen. Dass Prozesse der Selektion gegenüber der Platzierung als vorrangig einzustufen und stärker mit Autorisierung verbunden sind (vgl. die DSS-Handschriften, ähnlich auch die Anordnung der Bibelbücher in den Nebi'im und v.a. Ketubim), überzeugt. Die Verwendung von Psalmen(formationen) in (Fest-)Gottesdiensten am Tempel spricht gegen ein überdehntes literarisches Verständnis. Auch die Gebetsvollzüge sowie die vorausgesetzten Gemeindekontexte in den Psalmen sind gegenüber einem nachkultischen Verständnis zu bedenken. Ob Kompilation (Anthologie) oder Komposition (Buch) den Sachverhalt angemessener beschreibt, ist eher eine Frage des Masses als grundsätzlicher Art (der materiale Träger ist jedenfalls die Rolle). Auch wenn Psalmsequenzen und damit eingestiftete Sinndimensionen in der Rezeptionsgeschichte des Psalters wenig zum Tragen kamen, ist die Sache damit freilich nicht erledigt. Die neue Forschung hat vielfältige und auffällige Platzierungen, Reihungen und Gruppenbildungen diachron wie synchron bedacht (auf die Willgren nur am Rande eingeht), welche bedachte Anordnung bzw. „Komposition“ plausiblisiert. Die vom Vf. monierte fehlende Intentionalität ist kaum den Psalmisten, Anthologisten oder Redaktoren zu entlocken, sondern muss über die Gestalt bedacht werden (intentio operis). Anfragen lassen sich auch an seinen fast ausschliesslich historisch-diachron operierenden Ansatz stellen: Prozesse von Autorisierung- und Kanonisierung führten $\mathrm{zu}$ einem stabilen Gebilde eines Psalters (in den Umrissen von MT/LXX), der sich durchsetzte. Er will nicht nur in seiner Genese, sondern auch in seiner Geltung (und damit als Gesamtheit, insofern auch ,synchron“) bedacht sein. Die rekonstruierten Vorstadien Ps 1-119 und Ps 1-136 mögen Einblicke in die Formierungsgeschichte geben, sind aber hypothetisch und gegenüber der (,kanonischen“) Gestalt Ps 1-150 weniger bedeutend, weil „überholt.“ Unzureichend ist die für die Hauptthese wichtige Untersuchung zu Ps 1(-2) mit Ps 1,2 als Schlüsselaussage. Willgrens Deutung der „Tora JHWHs“ im Sinne von „Tora Moses“ (Pentateuch), also ausschliesslich extern-referentiell, ist engführend und nicht haltbar. Umfang wie Autorität der Tora sind ausgeweitet. Sie ist weder mit der des Mose noch (aufgrund der vertikalen Richtung) mit der eines Weisheitslehrers gleichzusetzen. Sie kommt „von oben“ (Gott) und wird empfangen bzw. eingeübt „von unten“ (Mensch), d.h. mittels Rezitation und Meditation einverleibt. Ein mündliches oder - eher verschriftetes „Korpus“ ist anzunehmen, die Fixierung auf eine bestimmte Rolle jedoch nicht (anders Jos 1,7-8). Die Annahme, dass aufgrund der Erststellung von Ps 1 auch die mit diesem Psalm eingeleiteten Psalmen als autoritative „Gottesweisung“ zu fassen sind, steht nicht explizit, gibt aber Sinn und lässt die Anfangssetzung dieses Psalms erst recht verstehen. Wer der Spur seiner Hinweise folgt, vermag zu erkennen, dass Ps 1 mittels Referenzen auf ent- 
scheidende Stellen im Pentateuch (v.a. Dtn) das „Buch“, das er einleitet, autorisierend an den Pentateuch (und die Nebi'im) anschliesst und zugleich eine Leseanleitung auf das Folgende bietet. Der Psalm transportiert eine anaphorische Funktion (Andockung des Psalters) wie eine kataphorische Funktion (Einführung des Psalter). Ihm eignet eine hermeneutische bzw. metatextliche Sonderfunktion. Das Verständnis von Ps 1 als Einweisung ist freilich nicht gleichzusetzen mit der Bestimmung des Psalters als Reflexion und Meditation. Ps 1 führt auf den Weg, das Psalmenbuch als Wort $z u$ Gott und Wort von Gott zugleich zu verstehen; im Psalter sind (weisheitliche) Lehre, Gebet und (gottesdienstliches) Lob miteinander verbunden.

Willgren hat mit seiner Studie die Psalterexegese herausgefordert, ihre Prämissen und Ergebnisse neu zu überdenken. Für die Neubestimmung hat er selbst einen wichtigen Beitrag geleistet. Auch wenn er nicht in allen Belangen überzeugt und selbst (zu) stark vereinseitigt (wie er der gängigen Psalterforschung vorwirft), so ist ihm für die grosse Arbeit zu danken.

Beat Weber, Basel, Guest Lecturer of the Old Testament at different Institutions (Germany, Switzerland) \& Research Associate of the Department of Ancient Languages and Cultures, University of Pretoria, Pretoria, South Africa. Email: weber-lehnherr@sunrise.ch. Doi: http://dx.doi.org/10.17159 /2312-3621/2017/v30n1a15. 